\title{
Russia's response to new types of threats of the XXI century
}

\author{
Tatyana Bespalova ${ }^{1, *}$, Maxim Bakhtin $^{2}$,Elena Sviridkina ${ }^{3}$, Vladimir Lepekhin ${ }^{4}$ \\ ${ }^{1}$ Russian Research Institute of Cultural and Natural Heritage named after D.S.Lihachev (Heritage \\ Institute), Russia \\ ${ }^{2}$ Publishing House "Encyclopedist-Maximum", Russia \\ ${ }^{3}$ Russian State Pedagogical University named after A.I. Herzen Washing embankment, building 48, \\ 191186, St. Petersburg, Russia \\ ${ }^{4}$ Institute of EurAsEs
}

\begin{abstract}
The need to form a new political philosophy is associated with modern challenges and threats that require large-scale ordering of the world of chaos and absurdity, an adequate response to the era of "post-truth" in order to preserve the national identity of peoples, cultures, civilizations, as well as the essential features of the person himself. The instability of international relations caused by the collapse of the bipolar world has given rise to the need to create a more stable polycentric world. Countering terrorism led to the formation of anti-terrorist coalitions at the international level and for a certain time brought the world community together in the fight against a common threat. However, no one expected that the new type of war would become another test for the development of a common strategy of counteraction by mankind, requiring a rethinking of the role of man in modern political processes. Schmitt's "friend-foe" confrontation may acquire a different content in the 21 st century, when man himself becomes his own enemy, since the products of his military-political and scientific activities endanger the life of all mankind. Russia's response to new political threats can be the development of a new value role of man in the emerging world order, which is possible on condition of world recognition of the civilizational originality of the Russian historical path, building a dialogue of civilizations, as well as the implementation of three ideologies in the new political dimension - patriotism, socialism, environmentalism.
\end{abstract}

\section{Introduction}

This paper is being written during the withdrawal from the air of N. Mikhalkov's program "Besogon" "Who has the state in his pocket?", which uses data from L. Savin's investigation about Bill Gates, whose name is constantly mentioned in connection with his interests in pharmaceutical campaigns, vaccinations and the activities of the WHO, and also raises the question of the goal of the Good Club's activities - overpopulation of the planet, limited natural resources, which, according to Bill Gates, requires a search for ways to reduce the population and includes not only the use of new types of weapons (biological,

\footnotetext{
* Corresponding author: tvb09@bk.ru
} 
bacteriological) and total media control over people, but also the simplification of education, a radical transformation of historical memory, which will certainly lead to the emergence of a new type of person (is it a person at all?). In fact, we are talking about a new type of bioracism ("ecological psychoterrorism"), the selection of the "chosen ones" on the basis of the idea of the caste division of society, who are worthy, according to someone's choice, for living on Earth. New types of threats have actualized the long-known truth - the cause of all wars is man himself [1]. Therefore, until such a "wonderful" world has come, we will try to build a strategy for preserving the civilizational community of Russia and, mankind in general, one of the conditions of which is the preservation of genuine historical memory, including the memory of the Great Patriotic War, of the great feat and spiritual strength of the Soviet people.

2020, the year of the 75th anniversary of the Great Victory, was declared the Year of Memory and Glory and promised to become unforgettable in world and national history in terms of political significance and scale of celebration. However, everything went completely differently. The two main holidays of Russia - Easter and Victory Day, reflecting the Christian and Soviet meaning of national life, in the usual forms of celebration fell out of the desired reality due to a new political threat, which has received various names in the scientific community "psychoterrorism", "Third World Psychic War", "viral-psychic-informational blow" (V. Lepekhin), "anthropogenic catastrophe caused by artificial coronavirus" (N. Denisov), "virus-humanist" (V. Rastorguev) and others. Regardless of the name, abstracting from conspiracy theories, analysts agreed on the main thesis - there is a force that launched and directs not only the coronavirus, but also mass psychosis and political actions around its spread. What is the meaning of what is happening?

The closer the Victory anniversary and the 75th anniversary of the UN approached, the more often rhetoric about the possible use of nuclear weapons began to sound, and Russia's proposals to NATO countries on a moratorium on the deployment of short- and mediumrange missiles did not receive support. The world, once again, found itself on the verge of a dangerous line - "conflict of civilizations" versus "dialogue of civilizations" (S. Huntington, A. Panarin), and in the first case, taking into account the development of the latest types of weapons, the last war in the history of mankind could take place.

A huge number of social calamities of the 20th century, wars, interethnic conflicts, unfortunately, did not lead to the solidarity of peoples, cultures, states. A new type of threat associated with the use of biological, mental and cyber weapons (all of them, of course, are associated with the United States, where it returned like a boomerang) revealed the absence of a common strategy for the emerging challenges even among civilizationally close countries (Russia-Belarus), as well as low professionalism of a number of security experts who allowed panic and mass psychosis.

New types of wars, the expansion of inequality and injustice in society, environmental threats, the ontological contradiction between man and artificial intelligence have highly actualized the question of man's place in the modern world and his value purpose, the ability of mankind to stand together in solidarity against a common threat.

The presented paper will outline problematic plots related to solving higher-level tasks that have long been predicted by scientists, military strategists, and science fiction writers, and will formulate the desired role of Russia in overcoming the threats that have arisen. Moreover, since 2012, in the documents of Russia's strategic planning in the field of foreign policy, national policy, culture, concepts have begun to be used that express the civilizational aspects of the development of Russia as a state-civilization: Russian civilization, a single cultural (civilizational) code, inter-civilization dialogue, Russia as a historical statecivilization, etc. The use of a civilizational approach (Panarin A.S., V.N. Rastorguev, Bespalova T.V. and others) and the concepts that implement it occurs for the first time in the history of the Russian state. 


\section{Materials and Methods}

The complexity of the application of any scientific theory in the field of public administration is associated with the passage of at least three stages: first - the creation of the theory itself and its adaptation to new political conditions; second - simplification of the conceptual apparatus and meanings, taking into account the addressee; third - the setting of protective "barriers" for passing the desired meanings at the legislative level. All these processes are usually latent and take place in conditions of tough political confrontation over the final meaning of the document. The authors of the paper took part in the development of the Strategy of the State Cultural Policy for the Period until 2030 and a number of other strategic planning documents and faced a whole range of problems - institutional, procedural, technological. Writing a strategic planning document requires not only the development of a theory, but also largely depends on the ideological beliefs of the authors. The ideological foundations of the civilizational approach have often remained outside the scope of scientific attention, while they are the starting point in the selection of the necessary scientific argumentation. The study of the worldview foundations of the civilizational approach makes it possible to formulate a response to the threats to humanity that have arisen in the $21 \mathrm{st}$ century, as well as to avoid the risk of using civilizational theories for political purposes. Obviously, the civilizational approach can be used both to substantiate the originality of the Russian civilization, and for its partial and even complete rejection [2].

Multiple changes in the civilizational landmarks of Russia - Kievan Rus - Tatar-Mongol invasion - Tsardom of Muscovy - Imperial Russia - Soviet Union - Russian Federation and the contradictory historical events did not affect the stable choice of the Russian civilizational path. The change in the civilizational guidelines of Russia was previously associated with the comprehension of three historical plots - the origin of the Russian state, the reform of Peter, and the revolution in 1917. Now the two more historical events of a civilizational scale are added - the collapse of the Soviet Union and the events of the Russian Spring, which returned not only the civilizational mission of Russia, but also changed the political situation in the modern world. Nowadays, the words expressed by the outstanding Russian philosopher A.S. Panarin two decades ago that in the post-Soviet period, "another - not the ideological, but the civilizational essence of the global conflict, previously ideologically stylized, began to be exposed quite sharply" are being confirmed. The political processes destroying Russian civilization have been going on for a long time and have global and local dimensions. In this regard, and taking into account the state and trends of international relations, A.S. Panarin's thesis about the right of Russia to have an original civilizational identity, about the right to be different from modern Western civilization, acquires special significance and meaning.

What does it mean to return to your own roots in the 21 st century? The bio-psychicinformational political threat of 2020 (in our opinion, the economic and political-legal content prevails over the medical one) made this issue even more relevant.

The description of the situation, which we will now give, is necessary for understanding further conclusions, despite the fact that at first glance, it seems that these plots have nothing to do with the declared topic. The dissemination of aggressive information around the viral infection on almost all federal channels in Russia and the world media, taken up by interested economic (pharmaceutical) and political circles, had a destructive effect on socially unprotected groups of people. The information was lined up effectively and vividly with the physiological details of the passage of the disease and subsequent death, which previously was always only in the introduction of the medical community. Almost no one raised the issue of protecting a person from information about the virus, about the number of strokes, heart attacks and the activation of chronic diseases of mankind under the influence of 
information. The choice of a person "not to watch the news" in order to maintain peace of mind was violated by passing cars with a speakerphone, reminiscent of the self-isolation mode. Panic and fear not only lower a person's immunity, but gradually erodes his spiritual essence. The regime of self-isolation, when a separate family had to build priorities (spiritual, material, cultural) in conditions of a huge flow of information destroying the human psyche, turned out to be within the power of not every person. As a protest reaction, which mainly became a form of self-defense and salvation from total interference in human life, people began to demand the opening of churches, return to their usual way of life with the opportunity to walk in the green zones of cities, etc. Protest sentiments based on citizen outrage at human rights violations swept across countries [3].

"Pandemic of fear" has become the dominant mood of 2020 all over the world (with the exception of a few countries - Sweden, Japan, Belarus). But can a person live in fear for a long time?

\section{Results}

According to V.N. Rastorguev, the nature of world evil is inexhaustible, new deadly viruses and scenarios for conducting bacteriological wars with selective purpose - in terms of racial and ethnic, age and gender orientation, have long been predicted as new types of wars not only by military strategists, but also by writers - science fiction writers, filmmakers. Of particular interest is the socio-political dimension that characterizes the widespread attitude towards the regime of self-isolation and associated with increased attention to the elderly. It is no coincidence that Rastorguev notes in his article with the humorous title "Again the Russians are to blame: even the virus is the Rus..." that "... politicians suddenly began to say that everything is being done to protect the elderly and even that it was they who were most restricted in their rights ... And why is it suddenly such a concern? Was it not them, old men, who were smoked out of life and especially zealously in the Russian Federation - at first, zeroing all savings and mocking the generation of winners, who were escorted accompanied by hooting of liberals and called nothing else but "homo sovieticus", and then introducing derisive pensions and even more derisive pension reforms? For some reason, it seems to me that they panic not because of ordinary old people, but because the country leadership itself has become physically and morally old". V.N. Rastorguev uses surprisingly accurate metaphors - "it's not a war, but a war situation", "regular reports from the fronts", "panic, worse than the epidemic itself", "everyone left, but not to the front, of course, but to some kind of remote work", and nevertheless comes to the conclusion that the pandemic is the lesser evil that possibly saved humanity from a dozen military conflicts with already calculated victims.

\section{Discussion}

The new civilizational challenge has made everyone equal.

The essence of the threat that has arisen is not in its peculiarities, but in the fact that people are faced with a certain deadly challenge, which they are not ready to resist. "And it is absolutely not important, as S.F. Chernyakhovsky notes in his works, what is the essence of this challenge (italics - T.B.): in salamanders emerging from the ocean, in an enduring fire on a Pacific island, burning the atmosphere of the earth, in predatory triffids breaking free from reserves and plantations, in a virus introduced to the planet or a virus escaping from military laboratories". Analyzing the current situation, the author draws attention to the plot of S. Lukyanenko's work "Stars are cold toys", describing how the basis for the authority of the mentors was laid by a terrible epidemic that reduced the population and completely 
destroyed one of the human races. "The second also stood on the verge of extinction, but was saved by mentors who discovered a medicine that had overcome the disease. The mentors became saviors and teachers who determine all the main points of the planet's development, which made it a powerful civilization of Good, Friendship and Peace. And almost no one knows that the mentors were able to save civilization and defeat the epidemic because it was they who created a deadly virus - at the same time creating an antidote for it". Chernyakhovsky concludes that a civilization that failed to make a transition to socialism before entering the stage of transnationality destroys itself in the course of its own development.

According to one of the versions, it was a planetary anthropogenic catastrophe that made a person fear himself, since he turned out to be too close to self-destruction [4 p.49]. The coronavirus as a product of scientific and other human activities has become a threat to its creator. The world of the future - what will it be? The release and complete absolutization of the biological nature of man, egoism, consumer attitude to the world in the conditions of the dominance of the economic over the human dimension of politics contributed to the establishment of chaos, the world of absurdity, the substitution of values, which, of course, should lead man and mankind to change socio-economic structure, the creation of a new philosophy of life. What will be the role of man in the new world, new ecological space? Will humanity be able to preserve itself in the conditions of "unenchanted nature"?

The semantic functions of the ecological worldview are associated with the problem of human survival [5], procreation, preservation of the main characteristics of the biological species of man, resistance to the artificial environment (there are forecasts about the possible rapid artificial evolution of a person whose life is subject to electronization processes). Man's overcoming of the "posthuman" in himself is the primary task of not only the environmental, but also the political worldview. It is necessary to build new relationships: human-God; human-human; human nature; human-artificial intelligence. In the latter case, one should not forget that robotic systems are not an extension of a human being, but a technology that simply allows solving tasks inaccessible to humans [6].

The limits of human adaptation to the environmental crisis reveal many problems associated not only with the preservation of natural resources, their careful use [7], but also with new ecological and biological threats. At the heart of the environmental crisis [8] is the problem of human adaptation to new environmental challenges, a person has ceased to feel the limits of the transformation of nature, not excluding himself from it. We are talking about scientific research of stem cells, genetic engineering, the problem of human cloning, surrogacy and other scientific research. A natural question arises: can we determine the fixed properties of a person as a biological species and a social organism and preserve them, or are we ready for cloning a person, creating a new type of living organisms and new ecological ethics [9]?

An interesting scenario can be the response of nature to the manifestation of the absolute freedom of man and his participation in the processes of active destructive influence on it. For nature, a person is too insignificant force and is just a biological species, the forces of nature are more powerful and can destroy a person not only by natural elements, but rather through self-destruction if a person will not be able to build new harmonious relations with nature and with himself. The proposals for solving acute environmental problems are contradictory, but in our opinion, the position of $\mathrm{V}$. Hösle is interesting, who believes that the environmental crisis can act as a common "enemy" for all mankind, but does not exclude the possibility that the search for various ways out of environmental crisis, the clash of conflicting interests will cause new wars. We are just now observing how different the strategies for countering a common threat [10] are - Chinese, American, Italian, Russian, Belarusian, Japanese, etc. It is this threat that may allow solving higher-level tasks related to 
the next reorganization of the world, and many things depend on the position that Russia will take now.

Within the framework of an atheistic worldview, the reasons for what is happening are biological, medical, environmental, military-political and financial-economic, while in a religious worldview that does not deny the above reasons, it is obvious that God allowed this situation and how it will turn out - evil or good - largely depends on the Russian position. Recently, "April theses" were written (Shcherbakov A.V., Kolesova L.A., Budanov, Altunin A.A. and others), in which the words of the Apostle Paul "We do not all die, but everything will change" and D.I. Mendeleev "We especially need well-educated people who closely know Russian nature, our entire reality so that we can take independent, not imitative steps in the development of our country" were taken as an epigraph: The authors characterize the current crisis not so much as a purely financial, economic or environmental crisis, but as a deep anthropological crisis of the consumer society, which requires a revision of the role of man in the modern world and his values.

Closed churches should remind a person of the greatness of God regardless of religion, the equality of the rich and the poor in the face of a common threat should lead to a rethinking of values and the blurring of boundaries between people on a material basis, the inefficiency of the health care system should actualize social policy issues, and the need to confront the threat should revive the significance of the "man of labor" and "man of science" in the social structure.

Will humanity be able to build a new world associated with the actualization of three ideologies in a new political dimension - patriotism, socialism [11], environmentalism in line with the original development of civilizations? Although, there is actually no choice.

Against this background, the problems of "wars of memory" seemed to have receded into the background, but in fact, it was the falsification of history that turned into one of the ways to reformat the world. And although the era in which we happened to be by the will of fate is characterized by large-scale changes in the processes of traditional perception of significant events in world and national history, "symbolic figures of memory", the feeling that they are trying in every possible way to drag Russia into a political discussion on historical topics on issues that are not at all controversial for us doesn't leave.

The well-known thesis of J. Assmann that "the memory of the past has nothing to do with scientific history" seems important, as well as his subsequent conclusion - historical memory as "a symbolic representation of the past, as an ideal reality combines various types of knowledge: not only scientific (primarily historical), but also religious, ideological, art, everyday knowledge" does not deny the scientific nature of the research, but rather complicates the perception of the past and gives it additional applied significance. Heroic "images of the past" in the history of peoples have always acted and are now acting as the most important symbolic resource, contribute to the legitimization of power, strengthening the solidarity of society, raising the people's spirit. After the victory in the Great Patriotic War, the Soviet Union became the main guarantor in preserving the new world order and peace. It was this role that allowed the Soviet power to change the balance of power in the world in favor of a socialist system, to achieve many victories in many areas from international to domestic politics. One of the main tasks facing the Russian people, the peoples of the post-Soviet space in the 21st century is the protection of the world for which the heroes of the Great Patriotic War gave their lives.

Now, the need for real integration of the post-Soviet space has become especially clear. And it should be done not on the basis of economic interaction, but, first of all, on the basis of common historical memory, maximum rapprochement and friendship of peoples, preservation of the identity of the Russian (in other political versions - Eurasian) civilization, the Eurasian Union. 
After 75 years, a huge number of organized "black" myths about this war have arisen in foreign historical memory, we will designate only a few:

- the equalization of the USSR and Nazi Germany in unleashing the Great Patriotic War, right up to the accusation of the Soviet government in acts of aggression;

- the accusation of Russia as the legal successor of the Soviet Union in the crimes of the Stalinist totalitarian regime;

- challenging the monopoly right to victory in the Great Patriotic War of the United States, Britain, allegedly victorious in the historical confrontation with totalitarianism, freeing Europe from Soviet despotism;

- accusing the Russian people of "imperial ambitions" in Russia's attempts to defend true historical memory;

- the perception of the originality of Russian civilization as a threat to the whole world;

- the imposition of a guilt complex on the Russian people, an attempt to clash the peoples of Russia on the basis of the return of "historical debts" (repression, etc.), accusing Russia of the absence of democratic traditions, of economic, cultural, and political backwardness;

- the demand for national repentance for the totalitarian past, etc.

The list of these far-fetched political accusations is endless. The goal is clear - the final destruction of the post-Soviet space, the memory of the heroic Soviet past, the maximum weakening of the role of Russia as the legal successor of the Soviet Union as the main victor of Nazism. This is not destined to come true. Russia will give a systematic response to the large-scale falsification of the memory of the Great Patriotic War, will no longer allow a total policy of anti-communism to be carried out on the territory of Poland, the Czech Republic, the Baltic States, Ukraine, etc. Careful tracking of informational stuffing, forecasting the situation and developing a long-term historical policy of the Russian state in the face of new political challenges will require the necessary ideological and philosophical support. The real protection of compatriots without regard to the position of Western countries, the restoration of a great power and the preservation of the memory of the great past of our beautiful Motherland - all these are priority tasks that require the manifestation of political will.

The radical manifestation of neo-Nazism [12] on the territory of the post-Soviet space can only be stopped by Russia with a new peacekeeping mission to restore historical justice. The right to a dignified and free existence of all citizens of the Russian state, including compatriots, whose honor and right to life have been repeatedly violated (Kondopoga, Transnistria, Donbass, etc.), must be constantly protected by the state. The greatness of the state is based not only on the memory of the great past of our beautiful Motherland, the exploits of the people, but also on the dignity of each person in the present and his confidence in the future.

The fragmentation of Victory began with criticism/denial of everything "Soviet" in the $90 \mathrm{~s}$ and the subsequent designation of some separate ethnocultural contribution of Ukrainians, Belarusians to the overall Victory, etc., and up to the point of absurdity. Gradually, all this led to the division of the common cultural and historical heritage into "national apartments", hostility over the "difficult" issues of history and, in the future, to the possibility of a radical revision of the role of the Soviet legacy throughout the world, which is unacceptable from the point of view of historical justice and conscience. The Soviet people were a multinational community, but least of all the soldiers in the fight against fascism, performing a great feat in the name of life on earth, paid attention to nationality. In the year of the 75th anniversary of the Victory, the peoples of the post-Soviet space had a chance to rethink their past, present and common future.

Why is Europe still so scared of the victory of the Soviet Union in one of the terrible wars of mankind? The answer is simple - the power of the memory of this war is too powerful to disappear, moreover, the upholding of this memory, with the will and desire of the people, can take more severe forms - it is no coincidence that the power of the Immortal Regiment 
(Memorial March) in the West is perceived as an increase in militaristic sentiments in Russia. In Russia, on the territory of the post-Soviet space (Belarus, Moldova, etc.), in the world (Bulgaria, Serbia, Canada, USA, Italy, etc.), the "Immortal Regiment" is perceived as a force of the Russian world, especially against the background of the dominant sentiments about the "degeneration" of the West.

\section{Conclusions}

Russia should again, like 75 years ago, act as an initiator of the reorganization of the world in line with the formation of a new type of eco-socialism in most countries, the revival of the civilizational identity of peoples and the building of an intercivilizational dialogue that will contribute to the solidarity of peoples, cultures and civilizations, a new role of man in 21 century.

In the recent large address of the President of Russia (28.04.2020), the choice of the story of Jack London - an American citizen and a socialist by conviction - is not accidental, as is the criticism of social Darwinism, the turn of the economic structure of society towards man, his interests and values (philosophy of love for man), the recognition of Russia as a separate civilization. Russia should act as a spiritual center and initiate voluntary unification of lands, real protection of compatriots, defend the position of the "Russian World", the originality of Russian civilization, its great thousand-year history. And not a single country will dare to contradict, since the new civilizational challenge concerns all of humanity. The new philosophy of life will be associated with a rethinking of the role of man, the revival of the hierarchy of values that will preserve the cultural and civilizational identity of peoples.

The civilizational mission of Russia in the political space of the 21 st century is the crystallization of the Russian (in spirit) patriotic political elite, the revival of the common cultural and civilizational space of Russia, Ukraine and Belarus, taking into account a single historical past, culture and language. "Great Russians, Little Russians, Belarusians are one people", and "Kievan Rus" is a period of Russian national history - this version of historical memory is still shared by the majority of Russian society. It is necessary to defend your memory and great homeland [13].

The existence and preservation of the viability of Russia as a state-civilization objectively requires the development of the ideology of state patriotism (in the work of Bespalova T.V., Sviridkina E.V. "Cultural and civilizational meanings of state patriotism") and the improvement of state politics in the spheres of culture, education, upbringing, information policy and other spheres, which corresponds to its goals and objectives, as well as state and economic structure.

By the fact of the presence of patriotism, all peoples are equal, but by the specifics of its manifestations are different [14]. In some studies, from the standpoint of constructivism, patriotism is seen as a delusion, the most common mistake [15], while in Russian philosophy and Russian political practice at the due level, on the contrary, without patriotism, serving one's country, genuine political action cannot arise.

Obviously, there are three most important basic values that determine the hierarchy of all other social values of Russian society, these are service to Russia, solidarity (the idea of solidarity civilization in the work of V.A. Lepekhin) and justice. The strengthening of Russian civilizational identity depends on the deciphering and actualization of various historical and cultural codes that make up the common symbolic space of the Russian tradition (Soviet values - the code of social justice, and Christian values - the evangelical code) (in the works of A.V. Shchipkov).

Russia's response to new political threats will be the development of a new value role of man in the emerging world order, which is possible on condition of world recognition of the civilizational originality of the Russian historical path, building a dialogue of civilizations, 
as well as the implementation of three ideologies in a new political space - patriotism, socialism, environmentalism. Russia, as a haven for the Spirit, must once again confirm its civilizational choice and offer the world a way out of the protracted crisis.

\section{References}

1. Marlene Belilos, Freud and war (London, 2018) https://doi.org/10.4324/9780429474996

2. T.V. Bespalova, Problems of civilizational development 1, 123-136 (2019) DOI 10.21146/2713-1483-2019-1-1-123-166

3. R. Tallise, Democracy After Liberlism. Pragmatism and Deliberative Politics (New York, 2005) https://doi.org/10.4324/9780203997680

4. R. Gottlieb, Cambridge Studies in Religion, Philosophy and Society (Cambridge University Press, Cambridge, 2019) https://doi.org/10.1017/9781316493083.002

5. E.A. Page, Climate change, Justice and future Generations (Cheltenham, UKNorthampton USA, 2006) https://doi.org/10.4337/9781845424718

6. T.V. Bespalova, Robots claim their rights: doctrinal and legal foundations and moral and ethical standards for the use of robotic technologies and devices: collective monograph (RIOR, Moscow, 2020) DOI: https//doi.org/10.29039/02027-2

7. M. Seymour, Pasific Philosophical Quarterly 92(2), 174-192 (2011) https://doi.org/10.1111/j.1468-0114.2011.01390.x

8. R.S. Morris, Preventive Veterinary Medicine 122(1-2), 242-252 (2015) https://doi.org/10.1016/j.prevetmed.2015.05.003

9. L. Westra, Environmental Justice and the rights of Ecological Refugees (London, 2009) https://doi.org/10.4324/9781849770088

10. I.M. Goklany, Is climate change the number one threat to humanity 3(6), 489-508 (2012) https://doi.org/10.1002/wcc. 194

11. E.V. Sviridkina, T.V. Mordovtseva, T.V. Bespalova et al, Journal of History Culture and Art Research 7(3), 444-451 (2018) DOI http://dx.doi.org/10.7596/taksad.v7i3.1748

12. Morality and Nationalism by Catherine Frost (London, 2006) https://doi.org/10.4324/9780203086179

13. V.Yu. Belsky, V.A. Lepekhin, Social and humanitarian knowledge 1 (2020) DOI: $10.34823 /$ SGZ.2020.1.51300

14. Mattias Kimm, International Journal of Constitutional Law 6(1), 117-136 (2008) https://doi.org/10.1093/icon/mom034

15. Jan-Werner Muller, Constitutional Patriotism (Princeton University Press, 2008) https://doi.org/10.1515/9781400828081 